\title{
Indian Demonetisation Announcement and Insights from Public Reaction : An Exploratory Study
}

\author{
Avinash $^{1 *}$ and Arunima, K.V. ${ }^{2}$ \\ ${ }^{1}$ Government First Grade College, Haleangadi, Mangalore, Karnataka, India \\ ${ }^{2}$ Department of Business Administration, Mangalore University, Mangalgangothri, Karnataka, India \\ *Corresponding author: avinashkotyan88@gmail.com
}

\begin{abstract}
This investigation analyses the early reaction of general public on demonetisation announcement, wherein, an attempt has been made to examine how people from diverse background perceived the decision in terms of its pros \& cons from the perspective of economy as well as from personal and business perspectives. A structured questionnaire survey is carried out via online and field survey mode during the period between $9^{\text {th }}$ November, 2016 and $11^{\text {th }}$ November, 2016. We utilise appropriate descriptive statistics and the ordinal regression model to get insights on our research objectives. The findings suggest that the demonetisation move is strongly appreciated by the citizens and considered it to be initiated at the right time despite the difficulties encountered by them with respect to procuring money from banks, post offices and ATM outlets in addition to the household and livelihood management during the initial three days. The results also prove that the younger generation, businessmen and professionals consider the demonetisation decision as the most appropriate as indicated by significant cumulative odds ratio. This implies that in the long run the decision India may witness more secure, brighter and prosperous economic and social growth.
\end{abstract}

Keywords: Currency, Demonetisation, Denomination, India, Ordinal Regression, Policy, Public

Since the opening up of the economy to private and global players under the Economic Policy-1991, India has witnessed multifaceted growth in all sectors. Kumar (2014) highlighted an annual growth rate of 14 percent in merchandise export during the period between 1995 and 2006. The growth in the gross domestic product has amplified from 1.1 percent level in 1991 to over 7 percent before demonetisation. The 1991's policy and other reforms introduced in the country have also contributed to drastic increase in per capita income, national income, employment opportunities and other economic growth indicators (Ravan, 2014; Anand, 2014). In spite of these, India could not utilise its full potentials due to several internal and external issues, like cross-border terrorism, tax evasion, hoarding of unaccounted money in foreign tax havens, counterfeit notes inflows and many more. These issues continue to torment the Indian economy and turnout be a major hindrance in country's progress. The past reports of government and non-government bodies give a clear picture about the intensity of impact of these problems. As per the report of Ministry of Finance (2012), the estimated amount of black money stacked up in tax havens is close to 15-45 percent of the size of Indian economy. The '2015 HSBC Leaks' revealed that over 1190 Indians deposited their illicit money in HSBC Geneva branch which sum up to INR254.2 billion and '2016 Panama Papers Leak' also provided similar facts with more than 500 Indians defied regulations and deposited untaxed money abroad (Hindustan Times, 2014; Sarin, 2015; British Broadcasting Corporation, 2015).

In case of counterfeit currency notes, the internal and external foes of the economy continue to pumpin huge volume of fake money into circulation. The Reserve Bank of India (2016) in its report stated that 
in 2015-16 seven in every million note is a counterfeit currency which is close to 0.63 million in number and value of these notes approximates to 0.0018 percent. Moreover, RBI is expecting that they can get minimum of 0.35 million fake notes accumulation via exchange of defunct currency channel after demonetisation announcement (Saha, 2016). Perhaps these notes weaken the economy on one hand and acts as a mode of sponsorship for illegal practices such as smuggling, illegal arms supply and terror financing on the other. In the light of all these challenges the monetary policy announcement made by the Prime Minister, Narendra Modi on November 8, 2016 seems to be a step forward in the right path to tackle all these issue. Many intelligent think-tanks including several rating institutions are highly positive about India becoming one of world's fastest growing economy in the next quinquennial as per the National Intelligence Council and the Moody's (The Economic Times, 2017; Business Standard, 2017).

Initiated with a primary focus on curbing the menace of black money, fake notes and terror-finance, the policy has also paved a way for making India a digital and less hard-cash society. The government has endorsed the move as 'short-term pain for longterm gain', but the decision has got mixed response from the experts and administrators. Several financial wizards, economists, opposition parties and quite a few state government called the strategy as mere policy gimmick. On the other hand, numerous corporates, few economists have appreciated the initiation taken up by the government. In order to bring the people's perspective to the demonetisation announcement, we made an attempt to analyse immediate reaction of public as more than $86 \%$ of the currency notes in circulation ceased to be a legal tender in a span four hours after its announcement by the prime minister. We also measured the pros and cons of the decision from economic, business and personal perspective of the respondents.

The remainder of this paper is structured as follows. Section 2 provides a survey of literature that portrays the views and opinions of economic and financial experts on demonetisation measure. The objectives of the study are listed out in section 3. Section 4 highlights the research methodology applied in the study. Section 5 provides a detailed discussion on the results of the investigation and concluding remarks on the study are presented in section 6 .

\section{Demonetisation - A Review}

Against the norm of RBI Governor announcing any monetary policy announcement in India, on $8^{\text {th }}$ November, 2016 at 8 p.m. in a television talk the prime minister of the country announced that existing INR500 and INR1000 currency notes would no longer be accepted as legal tender with a view to curb counterfeit currency, black money, future tax evasion and to crack down the use of illicit and counterfeit cash to fund for illegal activity and terrorism. By putting a cap on the money that one is able to deposit without coming under the scanner of the Income Tax department, the government aims at investigating possible current tax evasions as well. The Reserve Bank of India outlined a scheme for holders of such banknotes to either deposit them into their bank accounts for full/unlimited value or to exchange the banknotes for new with a penalty of almost 55 percent. While general public were allowed to exchange their old notes for valid currency up to INR3000 per day, deposit the money up to INR10000 during demonetisation period or withdraw a certain amount from the ATMs. The move saw unprecedented lines outside banks and ATMs with bank employees working overtime to make up for the cash crunch in the common man's life.

According to Dhara (2016) the circulation of Indian currency notes of all denominations was amplified to 40 percent $[76$ percent in case of INR500 notes and 109 percent in case of INR1000 notes] due to forgery of currency between the period 2011 and 2016 . The annual report of the Reserve Bank of India (2016) described that total value of bank notes in circulation was INR16.42 trillion (US\$240 billion), out of which approximately $86 \%$ (around INR14.18 trillion (US\$210 billion)) were of the denomination INR500 and INR1000 (Damodaran, 2016) and hence demonetisation was considered necessary.

Moving back to the Indian demonetisation history, the first currency ban in India was on January 11, 1946, when the government declared that notes of INR500, INR1000 and INR10000 will not be the legal tender from January 12, 1946. During this period, the defunct notes were being sold at 60 and 70 percent of their price and the move was considered 
as a death blow to black marketers (The Indian Express, 2016). The second currency ban was on $17^{\text {th }}$ January 1978, when notes of INR1000, INR5000, and INR10000 were demonetized by the then Prime Minister of India, Morarji Desai. The sole aim of the ban was to curb black money in the country. People who possessed these notes were given weeks' time to exchange any high denomination bank notes. Unlike Modi, Desai did not have the backing of RBI Governor. Then RBI Governor I.G. Patel believed that the ban was implemented simply to immobilize the funds of the opposition party and that people never store black money in the form of currency for too long. His move did not have much effect on the people and affected only the privileged few (Pimputkar, 2016).

Unlike the past, the present decision resulted in a tough cash crunch as it led to endless queues outside banks and ATMs across India, which became a daily routine for millions of people waiting to deposit or exchange the 500 and 1000 banknotes since $10^{\text {th }}$ November (The Hindu, 2016). ATMs were running out of cash after a few hours of being functional and around half the ATMs in the country were nonfunctional (Sangha, 2016). Most of the businesses were shut for the day and people were wrapping up from their day's work. Banks remained closed for the next day after the demonetisation announcement paralyzing the country for a day. Black money hoarders could not find a way out to funnel the black money, making it a full proof plan to nab all the hoarders under the tax radar.

In the first four days after the announcement of the measure, about 3 trillion (US $\$ 45$ billion) in the form of old 500 and 1000 banknotes had been deposited in the banking system and about 500 billion (US\$7.4 billion) had been dispensed via withdrawals from bank accounts, resulting in a total of 180 million transactions handled by the banking system (Ministry of Finance, 2016). Pani (2016) also reported a sudden increase in the usage of debit card and credit card after demonetisation. With respect to stock market activity, the next working day after the demonetisation announcement SENSEX and Nifty50 plunged nearly 1689 points and 541 points respectively (The Hindu, 2016) as a result of policy announcement and result of US presidential election. There was an adverse impact of the demonetisation on agriculture with low demand for food products prices of vegetables, food grains and other items fell drastically (Srinivas, 2016). Even e-commerce business witnessed decline of 30 percent with respect to cash-on-delivery orders (The Hindu, 2016) immediately after the announcement of demonetisation. The retail market for consumer durables and non-durables also affected as large denomination of purchases were electronic purchases (Economic Times, 2016). All EMIs of Chit funds are in the multiples of 500 and 1,000 rupees and people are not paying EMIs due to lack money in their hand (Arun, 2016). The real estate sector was hit by the decision as thousands of migrated construction workers have returned home due to no construction activity leaving some building sites across the country resulting in costly delays in almost all the projects (Singh and Wilkes, 2016).

This review clearly describes that there is a considerable impact of demonetisation announcement on various aspects of economic, business, societal and individual citizens' life. In order to verify how public has perceived the decision as soon as the announcement of demonetisation, we move further to collect their opinions about the policy announcement, difficulties faced by them, their view on policy impact, etc. for the period between $9^{\text {th }}$ November, 2016 to $11^{\text {th }}$ November 2016 with the objectives listed out in the section 3 .

\section{Research Objectives}

The demonetisation policy announcement resulted in some sort of chaotic situation in India as most of the currencies in circulation became defunct overnight. The currency exchange limits, time span to exchange, closure of banking activity on day following demonetisation announcement added to the increased panic in the minds of general public. In this back drop we assemble the opinion of public on the new policy measure with following objectives.

- To capture the early reaction of people on demonetisation.

- To identify the difficulties faced by the respondents during early days of note ban.

- To ascertain the appropriateness of the policy announcement from public perspective. 


\section{Data \& Methodology}

As soon as the announcement on demonetisation made by the Prime Minister, there were huge discussions among public about the pros and cons. The media was showering with information from the ministry, political leaders, economist and celebrities as such. Based on these discussions a structured questionnaire is prepared and collected responses from the public for the period between $9^{\text {th }}$ November and $11^{\text {th }}$ November 2016. We close the survey by the midnight of $11^{\text {th }}$ November as the objective of the study was to cater to the immediate response of the public. More than 1000 questionnaires are distributed online out of which 154 completed responses are received. The additional 87 responses are collected via field survey during these three days contributing to a total of 241 complete responses. Since the focus of this investigation is capture early response from the public, we consider the sample size of 241 is appropriate. The reliability of the questionnaire is tested using the Cronbach Alpha test which results in a value of the scale items as 0.82 , which indicates that the questionnaire is $82 \%$ reliable.

We analyse the early reaction of public and difficulties faced by them during the first three days of demonetisation using median, mode and simple descriptive statistics. The appropriateness of the decision from the perspective of public is captured using the Ordinal Regression Analysis (ORA), wherein, the data on appropriateness of the decision is considered as response variable and demonetisation utility measures such as, elimination of counterfeit currency \& black money, control over inflation rate, reduction of future tax evasion and controlling the use of mafia money in real estate represented in five point scale are entered as covariates (explanatory variables). This is done to verify whether opinions relating to utility of the decision matches with and helps to predict the respondents' opinion with respect to decision's appropriateness.

Furthermore, to assess the appropriateness of the decision from different age and occupational groups' perspective, we consider these two categorical measure as explanatory variable in the analysis. The case processing summary of these categorical factors along with our response variable is provided in table 1 . We categorise the respondents' age as youngsters $(<30)$, middle aged $(30-45)$ and veterans $(45+)$. Likewise, the occupational group is classified as academicians, professionals, business owners, employees of government and others represented by those citizens who do not come under working class such as housewife (homemaker), students and those who are a part of unorganised labour class.

The general expression of the ordinal regression model used in the study is:

$$
\begin{gathered}
\log i t Y_{i, j}=\alpha_{j}-\left[\sum_{i=1}^{n} \beta_{i} X_{1_{i}}+\sum_{i=1}^{p} \gamma_{i} X_{2_{i}}+\delta F+\varsigma B\right. \\
+\eta I+\lambda M+\theta T+\varepsilon_{j}
\end{gathered}
$$

where, $Y_{i, j}$ represents the cumulative probability of the $j^{\text {th }}$ category for the $i^{\text {th }}$ case; $\log i t Y_{i, j}$ indicates $\log$ of an odds ratio $\left[\log \frac{\psi}{1-\psi}\right]$ where, $\Psi$ probability of people in favour of demonetisation; $\alpha_{j}$ is the threshold/intercept value; $X_{1}$ and $X_{2}$ are factors in the ordinal regression model representing age group and occupational group with $\beta$ and $\gamma$ coefficients respectively; $n$ and $p$ indicate one less than total number of categories in age group and occupational groups respectively. The variables $F, B, I, M$ and $T$ are the covariates in the model representing public response on possible elimination of fake currency, black money, possible reduction in the rate of inflation growth, control over the investment of mafia money in real estate business and reduction/ control of future tax evasion possibilities respectively. The coefficients of these covariates are $\delta, \zeta, \eta, \lambda$ and $\theta$ respectively.

\begin{tabular}{|c|c|c|c|c|c|}
\hline \multicolumn{6}{|c|}{ Panel A : Decision's Appropriateness } \\
\hline & SD & D & $\mathbf{N}$ & $\mathbf{A}$ & SA \\
\hline $\begin{array}{c}\text { Frequency } \\
(\%)\end{array}$ & $08(3.3)$ & $09(3.8)$ & $40(16.7)$ & $\begin{array}{c}81 \\
(33.9) \\
\end{array}$ & $\begin{array}{c}101 \\
(42.3)\end{array}$ \\
\hline \multicolumn{6}{|c|}{ Panel B : Age Group } \\
\hline & \multicolumn{2}{|c|}{ Youngsters $\quad M$} & iddle Aged & \multicolumn{2}{|c|}{ Veterans } \\
\hline $\begin{array}{c}\text { Frequency } \\
(\%)\end{array}$ & \multicolumn{2}{|c|}{$104(43.5)$} & $96(40.2)$ & \multicolumn{2}{|c|}{$\begin{array}{c}39 \\
(16.3) \\
\end{array}$} \\
\hline \multicolumn{6}{|c|}{ Panel C: Occupational Group } \\
\hline & Teachers & Professionals & Business & $\begin{array}{l}\text { Govt. } \\
\text { Service }\end{array}$ & Others \\
\hline $\begin{array}{c}\text { Frequency } \\
(\%)\end{array}$ & $\begin{array}{c}55 \\
(23.0) \\
\end{array}$ & $61(25.5)$ & $40(16.7)$ & $\begin{array}{c}36 \\
(15.1) \\
\end{array}$ & $\begin{array}{c}47 \\
(19.7) \\
\end{array}$ \\
\hline
\end{tabular}

Table 1: Case Processing Summary Statistics

Note: The table reports a total of 239 responses complete responses out of 241 sample size. 
We check necessary model fit condition using baseline comparison and test the ordinal regression assumptions using multicollinearity test \& parallel line test to assess the suitability of our empirical approach. The ordinal regression model assumes no multicollinearity between each of the explanatory variables. This is because multicollinearity not only makes the estimates less efficient but also results in insignificant $t$ value but highly significant model fit criteria (Enders, 2013) which makes the overall model erroneous. We test this assumption using the Variance Inflation Factor (VIF) and the Tolerance value which has a limit of 10 and 0.10 respectively in case of these two statistics (Gujarati, 2011). The values below the VIF of 10 and values above the tolerance of 0.10 in each of the cases is an indication about the absence of multicollinearity problem.

Another underlying assumption pertaining to the ordinal regression is the assumption of proportional odds, which indicates the correlation between the response variable and explanatory variable does not change for response variable's categories; also parameter estimations do not change for cut-off points. In ordinal regression, the test on proportional odds examines the equality of the different categories and decide whether the assumption holds or not. If the assumption does not hold, interpretations about the results will be inaccurate (Erkan and Yildiz, 2014). We test this assumption with the help of full likelihood ratio test which compares the fitted location model to a model with varying location parameters (Laerd Statistics, 2013). The results of all these tests are discussed in the following section.

\section{RESULTS AND DISCUSSION}

In our investigation concerning the reaction of general public on demonetisation announcement majority of the respondents are in favour of the policy change. The brief summary of the study findings reveal that the respondents considers the decision as appropriate, initiated at right time and stresses the need for cash payment system along with digital payment mechanism. With respect to acceptance of the decision 71.8 percent of the respondents are happy and appreciate the decision, whereas, 18.7 percent, 6.6 percent and 2.9 percent of the respondents are confused, shocked and not accepted the decision respectively.
We use the opinion with respect to the decision's appropriateness, requirement of formalised (digital and banking based) payment system and selfpreparedness to face temporary hardship in order to capture the immediate reaction on demonetisation. The results of the same are provided in table 2. The descriptive statistics highlight that major portion of the respondents strongly agree that the currency ban decision is appropriate and they are ready to face the temporary hardship as modal value for the variables is 5 with favourable median value of 4 . In case of requirement of formalised payment system, the reaction of the respondents is in favour for the same as indicated by modal and median values which indicates a large portion of responses is concentrated on the Likert-scale indicator 'Agree'.

Table 2: Immediate Reaction of the Public

\begin{tabular}{ccc}
\hline Variables & Mode & Median \\
\hline Appropriate Decision & 5 & 4 \\
Formalised Payment System & 4 & 4 \\
Facing Temporary Hardship & 5 & 5 \\
\hline
\end{tabular}

Note: Likert scale data values range from 1-5, where 1 stands for strongly disagree and 5 stands for strongly agree.

We measure the difficulties faced by the respondents on the first three days of the announcement by gathering their response on scarcity of liquid cash, banks and post offices (POs) ability to support the policy measure. The same is reported in Table 3.

Table 3: Difficulties Faced by the Public

\begin{tabular}{cccccc}
\hline $\begin{array}{c}\text { Banks \& } \\
\text { Post Office } \\
\text { Performance }\end{array}$ & SD & D & N & A & SA \\
\hline $\begin{array}{c}\text { Frequency } \\
(\text { Percentage })\end{array}$ & 26 & 46 & 59 & 74 & 35 \\
$(10.8 \%)$ & $(19.1 \%)$ & $(24.5 \%)$ & $(30.7 \%)$ & $(14.5 \%)$ \\
\hline $\begin{array}{c}\text { Mode } \\
\text { Median }\end{array}$ & & 4 & \\
\hline $\begin{array}{c}\text { Sufficiency of } \\
\text { Cash }\end{array}$ & YES & 3 & NO \\
\hline $\begin{array}{c}\text { Frequency } \\
\text { (Percentage) }\end{array}$ & 101 & \multicolumn{3}{c}{140} \\
\hline
\end{tabular}

Note: Likert scale data values range from 1-5, where 1 stands for strongly disagree $(S D), 2$ stands for disagree $(D), 3$ stands for neutral $(N), 4$ stands for agree $(A)$ and 5 stands for strongly agree (SA).

Though almost $45.2 \%$ of the respondents suggest that banks and Post Offices (POs) are able to 
support the decision, perhaps these figure are not sufficient to accept the same and thus, we can deduce that the results are inconclusive in accepting the performance of Banks and POs in supporting the decision. On the other hand, it is quite clear that majority of the respondents are affected due to non-availability of sufficient cash either in hand or in ATMs which has created difficulties with respect to management daily household expenditures, monthly EMI payments and other daily \& monthly expenses as indicated by respondents.

Table 4 describes the statistics of variables pertaining to the opinion of public about impact of demonetisation on economic activities which is measured by gathering opinion on the adverse effect of the announcement on informal economy (i.e., on construction workers, petty shops, chit funds and contract labourers) along with its impact on business dealings. On account of demonetisation there was a sudden increase in online transactions (Pani, 2016; Bhalla, 2017) and there is equal possibility of increase in online threats which may adversely affect economic activities in the country at large. We consider all these variables to gauge the impact of the announcement on economic activities.

Table 4: Opinion on the Impact on Economic Activities

\begin{tabular}{ccc}
\hline Variables & Mode & Median \\
\hline Construction Workers & 4 & 4 \\
Chit Funds & 4 & 4 \\
Petty Shop & 4 & 4 \\
Contract Labourers & 4 & 4 \\
Other Segment of Informal Economy & 4 & 4 \\
Business Dealings & 4 & 4 \\
Online Security Threats & 4 & 4 \\
\hline
\end{tabular}

Note: Likert scale data values range from 1-5, where 1 stands for strongly disagree and 5 stands for strongly agree.

Table 4 indicates that majority of the respondents are of the opinion that there will be a negative effect of the decision on construction workers \& contract labourers whose livelihood depend on daily wages, on small chit funds whose customers/ stakeholders are daily wage labourers, on petty shop and other sections of informal economy \& formal business whose dealings largely in hard cash as all these variables show median and modal value of 4 on Likert scale. Moreover, the respondents are also in support of the claim that demonetisation will increase the possibility online threats as their opinions largely concentrated on the Likert scale value 'Agree'. All these findings highlight the possible adverse impact of the event on economic activities as per immediate reaction of the public.

Next, we analyse the usefulness of the policy announcement under the lime light of government's claim on elimination of fake currency, black money; reduction in inflation rate, tax evasion in future and other indirect benefits in the form of control on activities of land mafia. The results pertaining to these aspects are presented in table- 5 and both median and mode values indicate that majority of the respondents agree on the claim of the government on the utility of demonetisation.

Table 5: Opinion on Utility of Policy Announcement

\begin{tabular}{ccc}
\hline Variables & Mode & Median \\
\hline Elimination of Fake Currency & 4 & 4 \\
Elimination of Black Money & 4 & 4 \\
Reduction in Inflation Rate & 4 & 4 \\
Controlling Mafia Money in Real Estate & 4 & 4 \\
Reduction in Future Tax Evasion & 4 & 4 \\
\hline
\end{tabular}

Note: Likert Scale Data. Values range from 1-5, where 1 stands for Strongly Disagree and 5 stands for Strongly Agree.

In order to get a clear indication about the appropriateness of demonetisation announcement from citizens' perspective, we run ordinal regression with the appropriateness of demonetisation decision reflecting the opinion of public as response variable and purpose of demonetisation measured via elimination of counterfeit currency \& black money, control of inflation rate, reduction in future tax evasion and controlling the use of mafia money in real estate represented in five point scale as covariates along with age \& occupation based categorical variable.

We first, first report the results of model diagnostic statistics in table 6 to check whether the ordinal regression model used in the study satisfies all preconditions/assumptions. The test of multicollinearity which checks for the existence of high degree of correlation among explanatory variables indicate that our model is free from multicollinearity problem as VIF value is less than 10 and Tolerance value is greater than 0.10 for all the explanatory variables. 
Table 6: Test of OR Assumptions

\begin{tabular}{|c|c|c|c|c|c|c|c|}
\hline \multicolumn{8}{|c|}{ Panel A : Test of Multicollinearity } \\
\hline$\underbrace{\mathrm{Var}}_{\substack{\text { Collinearity } \\
\text { Statistics }}}$ & $\begin{array}{c}\text { Fake } \\
\text { Currency }\end{array}$ & $\begin{array}{c}\text { Black } \\
\text { Money }\end{array}$ & $\begin{array}{l}\text { Growth in } \\
\text { Inflation }\end{array}$ & $\begin{array}{c}\text { Real Estate } \\
\text { Mafia }\end{array}$ & $\begin{array}{l}\text { Future Tax } \\
\text { Evasion }\end{array}$ & Age Group & $\begin{array}{l}\text { Occupational } \\
\text { Group }\end{array}$ \\
\hline Tolerance Level & 0.614 & 0.551 & 0.687 & 0593 & 0.609 & 0.981 & 0.968 \\
\hline V IF & 1.629 & 1.816 & 1.455 & 1.685 & 1.641 & 1.019 & 1.033 \\
\hline \multicolumn{8}{|c|}{ Panel B : Test of Parallel Lines } \\
\hline Model & \multicolumn{3}{|c|}{-2 Log Likelihood } & Chi Square & D.F. & \multicolumn{2}{|c|}{$P-$ Value } \\
\hline Intercept only & \multicolumn{3}{|c|}{441.031} & & & \multirow{2}{*}{\multicolumn{2}{|c|}{0.8280}} \\
\hline General & \multicolumn{3}{|c|}{410.387} & 30.644 & 39 & 0.8280 & \\
\hline
\end{tabular}

The ordinal regression model used in the study is based on the fundamental assumption of proportional odds which highlights that an identical effect is observed for each explanatory variables at each cumulative split of ordinal response variable (Laerd Statistics, 2013). Here, we use the test of parallel lines to verify whether our model satisfies the proportional odds assumption, the result of which is presented in table 6; panel-B.

Since, the probability value of the test statistic is insignificant at $5 \%$ level of significance, we fail to reject the null hypothesis of the test that states that the location parameters (i.e., slope coefficients) are the same across response categories. This is an indication that our model also satisfies the assumption of proportional odds.

Before discussing the estimates of ordinal regression, we verify goodness of model fit by comparing the baseline model with the model used in the study. The significance of McCullagh and Nelder (1989) $\chi^{2}$ value shows that our model offers better prediction than simple intercept-only (baseline) model, which is similar to making guess based on marginal probabilities for the outcome categories (Elamer and Sadeq, 2010).

Table 7: Test of Overall Model Fit

\begin{tabular}{ccccc}
\hline Model & $\begin{array}{c}\mathbf{- 2} \text { Log } \\
\text { Likelihood }\end{array}$ & Chi Square & D.F. & P-Value \\
\hline $\begin{array}{c}\text { Baseline } \\
\text { Final }\end{array}$ & 592.375 & & & \\
\hline
\end{tabular}

After carrying out diagnostic checks and performing model fit verification, we proceed further to discuss the results of ordinal regression provided in table 8 . Among the covariates used to capture the influence on our response variable, all the variables relating to the government's motive behind demonetisation turnout to be statistically significant except the retort for the reduction in future tax evasion motive. The variable depicting the possible elimination of fake (counterfeit) currency indicates that a unit increase in the value of variable will result in an increase in odds in favour of the response on appropriateness of the demonetisation decision over the response on against the decision are greater than 1.454 times. Similarly, the odds of getting response in favour of demonetisation are greater if respondents are in prefers positive response pertaining to the response on control over black money, possible reduction in inflation growth rate and control over investment of mafia money in real estate as indicated by higher odds ratio relating to these variables.

In case of the categorical variable - age group, the results reveal that there is more possibility that youngsters and middle aged individuals are more likely to give positive response towards the appropriateness of demonetisation decision in comparison to veterans. The statistically significant value for youngsters category implies that the odds that youngsters are strongly in favour of demonetisation decision is 2.01 times greater than that of veterans as indicated by the cumulative odds ratio value. The reason that can be attributed for the youth considering the decision to be more appropriate than other age groups is they perceive that this decision could eliminate/control black money, corruption, counterfeiting of currency and could promote prompt payment of tax to the government and hence, they aspire for more secure, brighter future socially and economically in the long run. 
Table 8: Estimates of Ordinal Regression Parameters

\begin{tabular}{ccccccc}
\hline Variables & $\begin{array}{c}\text { Coefficient } \\
\text { Notation }\end{array}$ & Estimates & Std. Error & Wald Statistic & P Value & Odds Ratio \\
\hline Constant (SD) & $\alpha_{1}$ & 4.461 & 0.893 & 24.94 & $0.0000^{* * * *}$ & 86.602 \\
Constant (D) & $\alpha_{2}$ & 5.832 & 0.901 & 41.858 & $0.0000^{* * *}$ & 341.06 \\
Constant (N) & $\alpha_{3}$ & 8.063 & 0.971 & 68.922 & $0.0000^{* * *}$ & 3173.5 \\
Constant (A) & $\alpha_{4}$ & 10.36 & 1.061 & 95.308 & $0.0000^{* * *}$ & 31558.27 \\
Fake Currency & $\delta$ & 0.374 & 0.18 & 4.32 & $0.038^{* *}$ & 1.454 \\
Black Money & $\zeta$ & 0.525 & 0.143 & 13.435 & $0.0000^{* * *}$ & 1.691 \\
Inflation & $\eta$ & 0.523 & 0.166 & 9.905 & $0.002^{* * *}$ & 1.686 \\
Mafia Money & $\lambda$ & 0.797 & 0.168 & 22.398 & $0.0000^{* * *}$ & 2.219 \\
Tax Evasion & $\theta$ & 0.052 & 0.154 & 0.112 & 0.738 & 1.053 \\
\hline Age Group & & & & & $0.09^{*}$ & 2.01 \\
\hline Youngsters & $\beta_{1}$ & 0.698 & 0.412 & 2.87 & 0.195 & 1.726 \\
Middle Aged & $\beta_{2}$ & 0.546 & 0.421 & 1.679 & & 1 \\
Veterans & $\beta_{3}$ & 0 & & & & \\
\hline Occupational Group & & & & & 0.308 & 1.532 \\
\hline Academicians & $\gamma_{1}$ & 0.426 & 0.418 & 1.04 & $0.015^{* *}$ & 2.809 \\
Professionals & $\gamma_{2}$ & 1.033 & 0.423 & 5.971 & $0.08^{*}$ & 2.182 \\
Business & $\gamma_{3}$ & 0.78 & 0.446 & 3.06 & 0.234 & 1.735 \\
Govt. Service & $\gamma_{4}$ & 0.551 & 0.463 & 1.415 & & 1 \\
Others & $\gamma_{5}$ & 0 & & & & \\
\hline
\end{tabular}

Likewise, with regard to occupational groups the results suggest all the categories of work class more likely to give positive rating in favour of demonetisation decision compared to 'others' category represented by homemakers, students and unorganised labour class. However, results highlight statistically significant value only for two groups, that is, professionals \& businessman. The cumulative odds value relating to these two significant occupational groups is 2.809 \& 2.182 respectively and thus, the odds that professionals and businessman strongly favouring the decision is 2.809 and 2.182 times greater than that of group represented as 'others' respectively. Though these two occupational classes highly affected due to the announcement, like youngsters they have also expect more positive influence of the decision on the society and economy at large.

\section{CONCLUSION}

Initiated with the intension to cleanse Indian economy from the clutches of black money, counterfeit notes and terror financing; the demonetisation process has affected the public life to a greater extent. The prime minister, Narendra Modi's sudden announcement of scrapping two higher denomination currencies made entire country off-guarded and created panic in the societal life since more than 80 percent of currencies in circulation became defunct overnight. This immediate adversary might have prompted the citizens of the country to overlook the possible future benefits of new policy implications as innocent common men and sincere tax payers also caught in the demonetisation cross fire. With this background we examine immediate reaction of the demonetisation announcement from the public and difficulties faced during the first phase of demonetisation.

The results shows that majority of the public strongly appreciated the government's decision in spite of the chaos and difficulties involved in it. The study findings show that the respondents considers the decision as appropriate, initiated at the right time, useful in accomplishing motives of the government. They also recommend the need for cash based payment system along with digital payment mechanism. This is because a major portion India's population are not familiar with digital mode of payment and consider it less secure than cash based payment. In case of mode of execution of the demonetisation decision, the study 
suggest that general public life is adversely affected due to banks and POs inability in supporting the decision and non-availability of sufficient cash either in hand or in ATMs which has further added to the difficulties with respect to management daily household expenditures, monthly EMI payments and other daily \& monthly expenses as indicated by respondents.

The results of the ordinal regression analysis proves that the respondents with an age below 30 years are likely to prefer the demonetisation as against the rest of the respondents. Similarly, businessmen and professionals are strongly in favour of the decision compared to homemakers, students and unorganised work class as indicated by the cumulative odds ratio. Altogether, the findings upheld that majority of public have positive outlook toward the demonetisation decision in spite of the troubles they encountered during the first three days of demonetisation period. The reason for positive outlook towards the decision is due to the public belief that in long run demonetisation may help to eliminate/control black money, corruption, counterfeiting of currency and could promote prompt payment of tax to the government, which will make India's future more secure, brighter and prosperous economically as well as socially.

\section{REFERENCES}

Anand, N. 2014. An Overview of Indian Economy (19912013). IOSR Journal of Economics and Finance, 3(3), 19-24. Retrieved January 17, 2017, from http://www.iosrjournals. org/iosr-jef/papers/vol3-issue3/C0331924.pdf

Arun, K.C. (2016, November 14). Demonetisation to check unfair practices in chit fund sector. Kerala, India: Indian Express. Retrieved January 20, 2017, from http://www. newindianexpress.com/states/kerala/2016/nov/14/ demonetisation-to-check-unfair-practices-in-chit-fundsector-1538247.html

Bhalla, T. 2017. What do the numbers reveal about India's digital acceptance post-demonetisation? Your Story. India. Retrieved March 5, 2017, from https://yourstory. com/2017/02/digital-india-post-demonetisation/

Bhatt, A. 2016. PM Modi Announces Notes Ban in AntiCorruptio Move, Millions Face Cash Crunch. India: NDTV. Retrieved January 17, 2017, from http://www.ndtv. com/india-news/pm-modi-speaks-to-nation-tonight-at8-pm-1622948

British Broadcasting Corporation. 2015. HSBC leak: India to probe new 'black money' list. India: BBC. Retrieved January 18, 2017, from http://www.bbc.com/news/worldasia-india-31282677
Business Standard. 2017. India to become world's fastest growing economy in next 5 years: Report. Washington: Press Trust of India. Retrieved March 3, 2017, from http://www. business-standard.com/article/international/india-willbecome-world-s-fastest-growing-economy-in-next-5years-report-117020900455_1.html

Damodaran, H. 2016. Are banks equipped to replace 2,300 crore pieces of $₹ 500$ and $₹ 1,000$ notes? The Indian Express. Retrieved December 28, 2016, from http://indianexpress. com/article/opinion/web-edits/rs-500-rs-1000-notesare-banks-equipped-to-replace-1874-crore-pieces-ofnotes-4364746/

Dhara, T. 2016. Why Were the Notes Scrapped? RBI Chief, Economic Affairs Secy Explain. News 18. Retrieved December 28, 2016, from http://www.news18.com/ news/india/why-were-the-notes-scrapped-rbi-chief-andeconomic-affairs-secretary-explain-1309756.html

Elamer, E. \& Sadeq, H. 2010. Ordinal Regression to Analyze Employees' Attitudes towards the Application of Total Quality Management. Journal of Applied Qunatitative Methods, 5(4): 647-658.

Enders, W. 2013. Applied Econometric Timeseries (3 $\left.{ }^{\text {ed }}\right)$. New Delhi: Wiley India Pvt. Ltd.

Erkan, A. \& Yildiz, Z. 2014. Parallel Lines Assumption in Ordinal Regression and Anlysis Approaches. International Interdisciplinary Journal of Scientific Research, 1(3): 8-23.

Gujarati, D. 2011. Econometrics By Example (1 $\left.{ }^{\mathrm{ed}}\right)$. New York: Palgrave Macmilan.

Hindustan Times. 2014. How much black money do Indians have abroad? New Delhi, India: Hindustan Times. Retrieved January 17, 2017, from http://www.hindustantimes.com/ business/how-much-black-money-do-indians-haveabroad/story-oNEf43CZRUf36LjCDU1q6K.html

Kumar, M. 2014. Impact of Economic Reforms on India. International Journal of Informative $\mathcal{E}$ Futuristic Research, 1(7): 47-53. Retrieved January 17, 2017, from http://citeseerx.ist.psu.edu/viewdoc/ download?doi=10.1.1.599.4357\&rep=rep1\&type=pdf

Laerd Statistics. 2013. Ordinal Regression using SPSS Statistics. (Lund Research Ltd.) Retrieved June 18, 2017, from statistics.laerd.com: https://statistics.laerd.com/spsstutorials/ordinal-regression-using-spss-statistics.php

McCullagh, P. \& Nelder, J.A. 1989. Generalised Linear Models (2 ed.). London: Chapman \& Hall.

Ministry of Finance. 2012. White Paper on Black Money. New Delhi, India: Government of India. Retrieved December 13, 2016, from http://finmin.nic.in/reports/WhitePaper BackMoney2012.pdf

Ministry of Finance. 2016. Press Note_01122016. Press Information Bureau. RBI. Retrieved January 21, 2017, from http://finmin.nic.in/press_room/2016/press_ note_01122016.pdf

Pani, P. 2016. Credit/debit card usage surges on demonetisation. Business Line. Retrieved December 29, 2016, from http:// www.thehindubusinessline.com/money-and-banking/ 
creditdebit-card-usage-surges-on-demonetisation/ article9341080.ece

Pimputkar, S. 2016. India's history with demonetisation: From 1946 to 2016. The Freepress Journal. Retrieved December 28, 2016, from http://www.freepressjournal.in/featuredblog/indias-history-with-demonetisation-from-1946to-2016/988212

Ravan, S.V. 2014. Impact of LPG on Indian Economy. Prime International Research Journal, 1(4): 21-33. Retrieved January 17, 2017, from https://www.researchgate.net/profile/ Sanket_Ravan/publication/299623274_Impact_of_LPG_ on_Indian_Economy/links/5703565108aea09bb1a30fb9. pdf

Reserve Bank of India. 2016. Withdrawal of Legal Tender Status for ₹ 500 and ₹ 1000 Notes: RBI Notice. Mumbai: RBI. Retrieved January 15, 2017, from https://rbi.org.in/Scripts/ BS_PressReleaseDisplay.aspx?prid=38520

Saha, D. 2016. Demonetisation: Only 16 out of every 250 fake notes detected in 2015-16. India: The Business Standard. Retrieved January 19, 2017, from http:// www.business-standard.com/article/economy-policy/ demonetisation-only-16-out-of-every-250-fake-notesdetected-in-2015-16-116112400139_1.html

Sangha, K. 2016. Non-functional ATMs worsen cash crunch. The Tribune. Retrieved December 28, 2016, from http:// www.tribuneindia.com/news/chandigarh/community/ non-functional-atms-worsen-cash-crunch/322132.html

Sarin, R. 2015. Exclusive: HSBC Indian list just doubled to 1195 names. Balance: Rs 25420 cr. The Indian Express. Retrieved January 17, 2017, from http://indianexpress.com/article/ india/india-others/express-investigation-hsbc-indian-listjust-doubled-to-1195-names-balance-rs-25420-cr/

Singh, R.K. \& Wilkes, T. 2016. Headed home: workers abandon Indian building sites after cash crackdown. The Star. Retrieved January 3, 2017, from http://www.thestar. com.my/news/world/2016/12/12/headed-home-workersabandon-indian-building-sites-after-cash-crackdown/
Srinivas, N.N. 2016. How Demonetisation Has Affected India's Agricultural And Food Markets: Myths versus reality. Huff Post. Retrieved January 3, 2017, from http:// www.huffington post.in/nidhi-nath-srinivas/howdemonetisation-has-affected-indias-agricultural-andfood-ma_a_21608078/

The Economic Times. 2016. Demonetisation impact decoded: Gainers and losers . The Economic Times. Retrieved January 3, 2017, from http://economictimes.indiatimes.com/ wealth/personal-finance-news/demonetisation-impactdecoded-gainers-and-losers/articleshow/55348597.cms

The Economic Times. 2017. India to remain one of the fastest growing economies: Moody's. New Delhi: Press Trust of India. Retrieved March 3, 2017, from http://economictimes. indiatimes.com/news/economy/indicators/india-toremain-one-of-the-fastest-growing-economies-moodys/ articleshow/56604318.cms

The Hindu. 2016. Demonetisation of ₹ 500 and ₹ 1000 notes: RBI explains. India. Retrieved January 17, 2017, from http://www.thehindu.com/news/national/Demonetisation of ₹ 500 and ₹ 1000-notes-RBI-explains/article16440296.ece

The Hindu. 2016. E-commerce firms see 30\% decline in cash on delivery orders post demonetisation. The Hindu. Retrieved January 3, 2017, from http://www.thehindu.com/business/ Industry/E-commerce-firms-see-30-decline-in-cash-ondelivery-orders-post-demonetisation/article16643826.ece

The Indian Express. 2016. Demonetisation: Three times India faced the big move. The Indian Express. Retrieved December 28, 2016, from http://indianexpress.com/article/ india/india-news-india/demonetisation-narendra-modicurrency-ban-rs-500-rs-1000-1946-1978-4381683/

The Reserave Bank of India. 2012. Black Money - White Paper 2012. India. Retrieved January 2017, from http://finmin. nic.in/reports/WhitePaper_BackMoney2012.pdf 